\title{
Enhancement of diversity, stand structure and regeneration of woody species through area exclosure: the case of a mopane woodland in northern Botswana
}

Demel Teketay ${ }^{1 *}$, Keotshephile Kashe², Joseph Madome², Monica Kabelo², John Neelo², Mmusi Mmusi and Wellington Masamba ${ }^{2}$

\begin{abstract}
Introduction: An area exclosure is the practice of land management that involves the exclusion of livestock and humans from openly accessing an area that is characterized by severe degradation. Area exclosures have been employed as cheap and convenient means of rehabilitating degraded forests/woodlands. A study was carried out to (i) assess the species richness, diversity and evenness; (ii) determine the densities, frequencies, dominance and importance value index; and (iii) assess the population structure and regeneration status of woody species inside and outside the fence (area exclosure) of Okavango Research Institute (ORI) located in Maun, northern Botswana.

Results: Thirty-five woody species were recorded inside (32 spp.) and outside (24 spp.) the ORI compound, and the population structure and regeneration status of the woody species were better inside than outside the ORI compound. The exclosure had seven times higher mean density of woody species than outside ORI, and an exceptional regeneration of seedlings was observed inside than outside the ORI compound, suggesting the process of recovery of the degraded woodland. The frequencies of more than half of the woody species also showed increment inside than outside the exclosure. The results suggest that the exclosed area is still in an initial recovery stage since it had been an open grazing area prior to the establishment of the exclosure. Most of the woody species encountered outside ORI showed hampered recruitment and regeneration, owing to different anthropogenic impacts and overgrazing by animals.

Conclusions: Despite the relatively short period (10 years) of exclosure establishment, results from the present study have further provided empirical evidences on the actual crucial roles played by area exclosures to increase woody species richness, diversity, evenness, density, frequency, dominance and important value index as well as enhance the population structure and regeneration of the woody species in northern Botswana. Future research is recommended focusing on comparative studies on herbaceous species richness, diversity and density, horizontal and vertical distribution of soil seed banks, species richness of soil microorganisms, plant and soil biomass, plant and soil carbon pools (above and below ground) as well as soil contents and properties inside and outside the ORI compound.
\end{abstract}

Keywords: Frequency, Density, Important value index, Maun, Population structure, Species richness

\footnotetext{
* Correspondence: dteketay@yahoo.com; dteketay@buan.ac.bw; demelteketay@gmail.com

'Department of Crop Science and Production, Botswana University of

Agriculture and Natural Resources, Private Bag 0027, Gaborone, Botswana

Full list of author information is available at the end of the article
} 


\section{Introduction}

Mopane woodlands cover an estimated $550,000 \mathrm{~km}^{2}$ of land in southern Africa and are the dominant vegetation type in southern Angola, northern Namibia, northern Botswana into Zimbabwe, and central and northern Mozambique, southern Zambia, Malawi and northern South Africa (Mapaure 1994; Makhado et al. 2012; Makhado et al. 2014; Makhado et al. 2016; Woollen et al. 2016). Colophospermum mopane (Kirk ex Benth.) Kirk ex Leonard (mopane) is the dominant tree or shrub within mopane woodlands.

Mopane woodlands are among the woodlands in Africa that hold unique and diverse flora, which have actual and potential environmental, economic and social benefits (Shackleton et al. 2007; Makhado et al. 2012; Kalaba et al. 2013; Makhado et al. 2014; Makhado et al. 2016; Woollen et al. 2016). They have been referred to as social woodlands, with millions of rural and urban people relying on them to provide ecosystem services and livelihood benefits (Woollen et al. 2016). The direct uses of these mopane woodlands include fuelwood, poles, medicine, mopane worms, stink bugs, termites, edible locust, thatching and sweeping grasses, which are harvested, mostly by women, in order to meet household needs, such as food and energy, and generate incomes (FAO 2002; Makhado et al. 2012; Woollen et al. 2016).

As C. mopane wood burns slowly and produces good coals (Tietema et al. 1991), it is extensively used as firewood by rural communities in countries of southern Africa, including Botswana, where an estimated 79 million people depend on biomass as their main source of fuel (Karekezi and Ewagata 1994). Mopane woodlands also provide nutritious fodder for browsers, particularly in the dry season (Makhado et al. 2012; Makhado et al. 2016). The leaves are preferred by browsers during winter when the tannins have leached out. The grasses under $C$. mopane trees are also quite nutritious and are highly preferred by grazing animals.

Non-wood products, which are, mainly, harvested by women for subsistence and commercial purposes include bee honey, mopane worms, locust, termites and stink bugs (Makhado et al. 2012). Insects, such as mopane worms, locust, termites and stink-bugs, which are harvested from mopane woodlands, form an important protein source to many rural people and constitute a lucrative income for rural traders. For example, in Botswana, the mopane worm harvest in a good year has been estimated to be worth US\$ 3.3 million, providing employment to 10,000 people (Ghazoul 2006). Similarly, the annual population of mopane worms in South Africa has been estimated at US\$ 57 million.

However, unsustainable use of mopane woodlands, lack of responsibility to effectively manage these woodlands and their conversion to other land use types are depriving rural communities from full range of benefits that could be harvested from the mopane woodlands (Makhado et al. 2012). Disturbances of both natural and human origin influence forest/woodland dynamics, woody species diversity, regeneration and dominance (Lawes et al. 2007; Sapkota et al. 2009; Neelo et al. 2015, 2015). Several studies (Vetaas 1997; Sheil 1999; Venkateswaran and Parthasarathy 2003; Lawes et al. 2007) have explained the relationship between disturbance and species richness, but the studies that elucidate how disturbances influence stand structure, species composition and regeneration of tree species are very limited, and this is also the case in Botswana (Neelo et al. 2015).

In the recent past, establishment of area exclosures (also known as 'area enclosures', 'area closures' and 'enclosures') has been employed as a cheap and convenient means of rehabilitating degraded forest/woodland areas in Ethiopia and elsewhere in the world. An area exclosure is the practice of land management that involves the exclusion of livestock and humans from openly accessing an area that is characterized by severe degradation (Aerts et al. 2009; Teketay et al. 2010). The purposes of area exclosures are to prevent further degradation of the ecosystems, advance re-vegetation/forest regeneration and restore the overall ecological conditions of the areas. In area exclosures, rehabilitation/restoration is primarily a natural process and human inputs are limited to offering protection against interferences. For this reason, some call it 'zero management' strategy for rehabilitation. The zero management makes it also the cheapest method of rehabilitation of degraded areas.

Various studies have been carried out on area exclosures that have been established in the different parts of the world. However, a thorough review of the available global literature reveals that the major and pioneering research results on area exclosures have been generated from Ethiopia over the years.

The research on area exclosures in Ethiopia focused on various themes, i.e.:

(i) Enhancement of plant species diversity and density as well as population structure and regeneration status of woody species (Mengistu 2001; Birhane 2002; Birhane et al. 2004, 2006, 2007; Mengistu et al. 2005a; Abebe et al. 2006; Yami et al. 2006, 2007; Mamo 2008; Yayneshet et al. 2009; Angassa and Oba 2010; Tekalign 2010; Abiyu et al. 2011; Getsesellasie 2012; Mekuria and Veldkamp 2012; Gratzer and Abiyu 2013; Abesha 2014; Lemenih and Kassa 2014; Mulugeta 2014; Yirdaw et al. 2014; Mulugeta and Achenef 2015; Kasim et al. 2015);

(ii)Improvement of plant biomass (Yayneshet et al. 2009; Yayneshet 2011; Getsesellassie 2012; Mekuria and Veldkamp 2012); 
(iii) Increment of density and diversity of large wild animals (Yami et al. 2007; Yirdaw et al. 2014);

(iv) Improvement of various aspects of soil resources and the associated edaphic conditions of degraded landscapes (Descheemaeker et al. 2006; Descheemaeker et al. 2006; Mekuria et al. 2007; Mamo 2008; Tsetargachew 2008; Girmay et al. 2009; Mekuria et al. 2009; Abiyu et al. 2011; Mekuria and Aynekulu 2011; Yayneshet 2011; Mekuria 2013; Abebe et al. 2014; Abesha 2014; Lemenih and Kassa 2014; Yirdaw et al. 2014; Naudts et al. 2015; Yimer et al. 2015);

(v) Enhanced soio-economic contributions (Nedessa et al. 2005; Babulo et al. 2006; Babulo et al. 2009; Tilahun et al. 2007; Tekalign 2010; Mekuria et al. 2011, 2011; Haile 2012; Getsesellassie 2012; Yirdaw et al. 2014; Mulugeta and Achenef 2015; Kasim et al. 2015);

(vi) Restoration of ecosystem carbon stocks (Mekuria et al. 2011, 2011; Getsesellasie 2012; Gratzer and Abiyu 2013; Yirdaw et al. 2014; Naudts et al. 2015; Yimer et al. 2015);

(vii) Effectiveness of management and governance of area exclosures (Mengistu 2001; Birhane 2002; Mengistu et al. 2005b; Birhane et al. 2006; Gratzer and Abiyu 2013; Yami et al. 2013; Lemenih and Kassa 2014; Yirdaw et al. 2014); and

(viii) Root colonization of arbuscular mycorrhizal fungi (Birhane et al. 2017).

Elsewhere, area exclosures have also been studied in the Mokolodi Nature Reserve of southeastern (Flyman 1999; Käller 2003; Bengtsson-Sjörs 2006; Leife 2010; Herrera 2011) and northern Botswana (Neelo et al. 2015, 2015), Kenya (Verdoot et al. 2009; Verdoodt et al. 2010; Mureithi 2006; Mureithi et al. 2014; Young 2015a; 2015b), Iran (Husseinzadeh et al. 2010), South Africa (Mbatha and Ward 2010) and United States of America (Siebert et al. 2010; DeStefano et al. 2015; Young 2015a, 2015b).

The first five studies on the area exclosure in Botswana mentioned above were carried out at different times following the establishment of an experimental area exclosure in 1997 to exclude large herbivores in the Mokolodi Nature Reserve, southeastern Botswana. They focused on the fate of seedlings of woody plants in the presence and absence of large herbivores (Flyman 1999), growth pattern and reproduction of woody vegetation (Käller 2003), and establishment and survival of woody seedlings (Bengtsson-Sjörs 2006), both of which were carried out in 2001, and changes in woody vegetation (Leife 2010) and spatial structure of woody savanna vegetation (Herrera 2011), both of which were carried out after 11 years of the area exclosure establishment.

The results of these studies revealed that the seedling density found during the seedling survey was unexpectedly high in both the exclosure and open areas investigated (Käller 2003; Bengtsson-Sjörs 2006) and the density of seedlings was roughly four times as high as that observed by Flyman in 1999 (Bengtsson-Sjörs 2006), the number of woody seedlings was higher in the open areas than in the exclosure; though the difference was not statistically significant (Bengtsson-Sjörs 2006), there was no significant difference in change in the density of trees (Leife 2010; Herrera 2011), species composition or proportion of spinescence trees between the open areas and the exclosures (Leife 2010), and general increase in stem density of woody species (by 63\%) from 1997 to 2007/ 2008 (Herrera 2011).

The other study in northern Botswana was carried out in an area exclosure established in the early 1980s (Island Safari in Maun, in close proximity with the current study area) in comparison with two areas representing open areas (Shorobe and Xobe) (Neelo et al. 2015). The results of this study reavealed that of the total 47 species, representing 16 families and 24 genera recorded in the three sites, 33 species representing 13 families and 20 genera were encountered in Island Safari, 41 species representing 15 families and 23 genera were encountered in Shorobe and 27 species representing 10 families and 14 genera were encountered in Xobe. The diversity values of woody species encountered were 2.18 in Shorobe, 2.15 in Island Safari and 1.5 in Xobe, while their corresponding evenness values were 0.6 in Shorobe, 0.6 in Island Safari and 0.5 in Xobe. The densities of the woody species encountered in Island Safari, Shorobe and Xobe were 2629, 4271 and 2745 individuals $\mathrm{ha}^{-1}$, respectively.

As stated above, mopane woodlands are central to the livelihoods of rural communities in southern Africa, i.e. Angola, Botswana, Malawi, Mozambique, Namibia, South Africa, Zambia and Zimbabwe, as these woodlands are used to meet a variety of needs. However, there have been growing concerns on the decline and degradation of these resources caused by various factors, including unsustainable harvesting practices by resource users, recurrent fire and overgrazing (Musvoto et al. 2007; Mapaure and Ndeinoma 2011; Makhado et al. 2012). As a result, there is a need to promote the sustainable use of mopane woodlands, including the rehabilitation/restoration of deforested and degraded lands. Establishment of exclosures has been recommended as a cheap and convenient means of rehabilitating deforested and degraded sites. Hence, the results from the present study would be instrumental in initiating and managing exclosures to rehabilitate/restore similar degraded woodlands in other countries of southern Africa.

Here, we report results of a comparative study of diversity, stand structure and regeneration status of woody species in an area exclosure ( $>10$ years old) and open 
areas adjacent to the area exclosure in a mopane woodland located in northern Botswana. The specific objectives of this study were to (1) assess the diversity (species richness, diversity and evenness), (ii) determine the stand structure (densities, frequencies, dominance and importance value index) and (iii) assess the population structure and regeneration status of woody species inside and outside the area exclosure.

\section{Methods}

\section{Study areas}

The study was carried out in Maun, northern Botswana, located at $19^{\circ} 59^{\prime} 39.01^{\prime \prime} \mathrm{S}, 23^{\circ} 25^{\prime} 06.24^{\prime \prime}$ E. Maun has a population of about 50,000 people and is the administrative centre of Ngamiland District. It is also the headquarters of numerous safari and air-charter operations that run trips into the Okavango Delta, one of the world's renowned touristic destinations, which has been endorsed as the 1000th World Heritage Site in June 2014 (UNESCO 2015). Since Maun is situated at the gateway to the Okavango Delta and Moermi Game Reserve, almost all tourists enter the Okavango Delta through it.

The study was undertaken in a mopane woodland of northern Botswana. The mopane woodlands in Botswana cover $85,000 \mathrm{~km}^{2}$, i.e. $15 \%$ of the total land mass of the country and $16 \%$ of the total area covered by mopane woodlands in southern Africa (Mapaure 1994). The dominant tree species in mopane woodlands is C. mopane, and it is one of the most important tree species in the mopane woodland, which is widely used for firewood, construction and medicinal purposes (Makhado et al. 2012). Poles of C. mopane are highly valued for construction of traditional structures because they are durable, termite-resistant and relatively straight. They are used for the construction of traditional huts, maize granaries, fences, animal kraals and utensils, such as mortars, pestles and wooden spoons. The species also hosts the lucrative mopane worms, which are consumed in large numbers by rural as well as urban people and sold to generate incomes. They are excellent sources of protein and even considered a delicacy in Botswana. The mopane worms form the basis of a multi-million Botswana Pula trade, providing livelihoods for many harvesters, traders and their families. Makhado et al. (2012) have summarized the medicinal uses of the leaves and bark of the mopane species as follows: relieving stomach pain and treating diarrhoea; against whooping cough, cancer and syphilis; and stopping excessive bleeding. The roots are used to avoid gum bleeding and as treatment of kidney stones, bilharzia, vomiting and healing of wounds.

Specifically, the study was carried out inside and outside of the compound of Okavango Research Institute
(ORI) located in Maun. ORI is a research institute dedicated to the study of wetland and watershed management in the Okavango River Basin, Southern African Development Community (SADC) region and beyond. ${ }^{1}$ Before the establishment of ORI, exclosed in a fenced compound more than 10 years before the current study, the study area used to support a uniformly highly degraded mopane woodland. Since the inside and outside parts of the ORI compound are adjacent, only demarcated by a fence, no or very little environmental heterogeneity were assumed in the study. At the time of the study, the fenced compound of ORI represents a mopane woodland with low anthropogenic disturbances since the fence has created an area exclosure that has prevented open access to grazing animals and poachers of woody species. The open mopane woodland located outside the fence of ORI represents the area with high anthropogenic disturbances.

The climate in the study area is semi-arid. Though it is hot and dry for much of the year, there is a rainy season, which runs through the summer months. Rainfall tends to be erratic, unpredictable and highly regional. Often, a heavy downpour may occur in one area while 10 or $15 \mathrm{~km}$ away there is no rain at all. Showers are often followed by strong sunshine so that a good deal of the rainfall does not penetrate the ground but is lost to evaporation and transpiration. The rainy season is in the summer, with October and April being the transitional months. January and February are generally regarded as the peak months. The mean annual rainfall in Botswana varies from a maximum of over $650 \mathrm{~mm}$ in the extreme northeast area of the Chobe District to a minimum of less than $250 \mathrm{~mm}$ in the extreme southwest part of Kgalagadi District.

Summer days in Botswana are hot, especially in the weeks that precede the coming of the cooling rains, and temperatures rise to the $38{ }^{\circ} \mathrm{C}$ mark and higher, reaching a blistering $44{ }^{\circ} \mathrm{C}$ on rare occasions. Winters are clear-skied and bone-dry, the air seductively warm during the daylight hours, but because there is no cloud cover, cold at night and in the early mornings. Sometimes bitterly so-frost is common and small quantities of water can freeze. During the morning period of the summer, humidity ranges from 60 to $80 \%$ and drops to between 30 and $40 \%$ in the afternoon. In winter, humidity is considerably less and can vary between 40 and $70 \%$ during the morning and fall to between 20 and $30 \%$ in the afternoon (http://www.botswanatourism.co.bw/climate, accessed on 30 Dec 2017).

In addition to $C$. mopane, the vegetation in the study area is dominated by Vachellia tortilis (Forssk.) Galasso \& Banfi, Grewia spp., Croton megalobotrys Müll. Arg., Philenoptera violacea (Klotzsch) Schrire, Vachellia erioloba (E.Mey.) P.J.H.Hurter and Terminalia prunioides Laws. (Fig. 1, Teketay et al. 2009). 

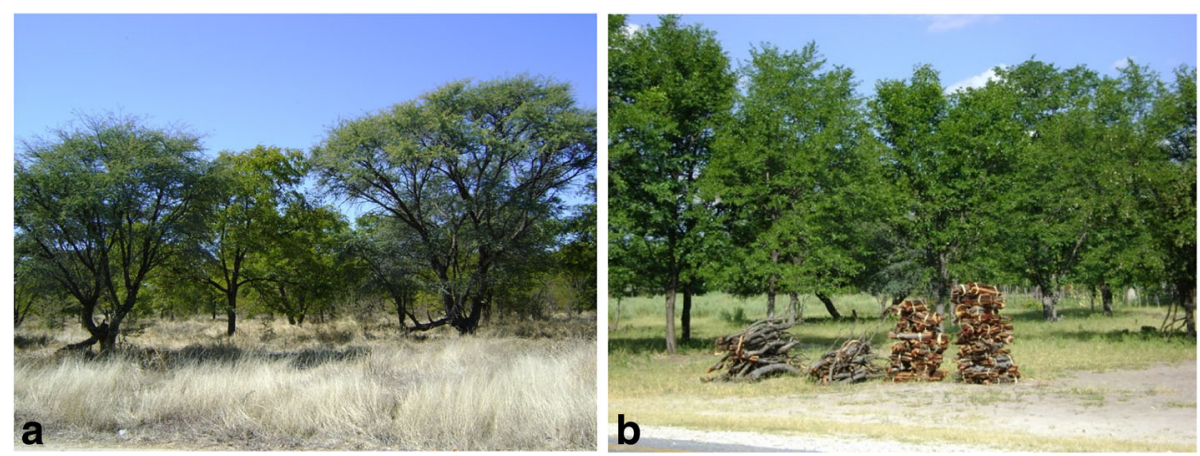

Fig. 1 The mopane woodland inside (a) and outside (b) the compound of Okavango Research Institute (note the fuelwood collected for sale in b) (photos by Demel Teketay)

\section{Data collection}

To determine the species, genera and family richness, diversity and evenness, stand structure (density, abundance, frequency, dominance, population structure and important value index) and regeneration status of the woody species, nine and 10 parallel line transects, $50 \mathrm{~m}$ apart from each other, were used inside and outside the ORI compound, respectively. Quadrats measuring $20 \times$ $20 \mathrm{~m}\left(400 \mathrm{~m}^{2}\right)$ were laid down along the parallel line transects at evey 50-m interval. For the study, a total of 69 quadrats were assessed in ORI and 41 quadrats were assessed outside ORI. The transects outside the ORI compound were shorter than those inside the ORI compound owing to settlements of people, leading to lower number of quadrats studied. In each of the quadrats, the following data were recorded: identity of all woody species, number of all live individuals and diameter at breast height $(\mathrm{DBH})$ of individuals with $\mathrm{DBH}>2 \mathrm{~cm}$ of each woody species encountered. In the case of juveniles (seedlings and coppices $<1.5 \mathrm{~m}$ height), the total number of individuals of each woody species was counted and recorded in each quadrat. A calliper and graduated measuring stick were used to measure $\mathrm{DBH}$ and height, respectively.

The woody species were identified directly in the field by using the available literature (Timberlake 1980; Ellery and Ellery 1997; van Wyk and van Wyk 1997, 2007; Heath and Heath 2009; Roodt 1993, 1998; Setshogo 2002, 2005; Setshogo and Venter 2003). Plant nomenclature in this article follows that of Setshogo and Venter (2003); Kyalangalilwa et al. 2013 and Setshogo (2005).

\section{Data analyses}

Species richness (S) is the total number of different woody species recorded in the study areas and does not take into account the proportion and distribution of each woody species.

Jaccard's Similarity Coefficient (Krebs 1989) was used to compute similarity in floristic composition of woody species, families and genera between the areas inside and outside the ORI compound. The diversity of woody species was analysed by using the Shannon Diversity Index $\left(\mathrm{H}^{\prime}\right)$ (also known as the Shannon-Weiner/ Weaver Diversity Index in the ecological literature) (Krebs 1989; Magurran 2004). The index takes into account the species richness and proportion of each woody species in all sampled quadrats. Evenness or equitability, a measure of similarity of the abundances of the different woody species in the sampled project sites, was analysed by using Shannon's Evenness or Equitability Index (E) (Krebs 1989; Magurran 2004). Equitability assumes a value between 0 and 1 with 1 being complete evenness.

The mean density of each woody species per hectare, both inside and outside the ORI compound, was determined by converting the total number of individuals of each woody species encountered in all the quadrats of each transect to equivalent number per hectare. The mean density of all woody species per transcet were, then, calculated by summing the densities of all woody species recorded in the transect. Then, the total mean densities of all woody species inside and outside the ORI compound were calculated from their mean densities in all the transects encountered inside and outside the ORI compound, respectively. Both mean densities of each woody species and total mean densities of all woody species inside and outside the ORI compound were subjected to two-sample $t$ test to determine if there were statistically significant differences between them (Zar 1996).

The frequency was calculated as the proportion (\%) of the number of quadrats in which each woody species was recorded from the total number of quadrats in the study site. The dominance of the woody species, with diameter at $\mathrm{DBH}>2 \mathrm{~cm}$, was determined from the space occupied by a species, usually its basal area (BA). It was computed by converting the total basal area of all individuals of each woody species to equivalent basal area per hectare (Kent and Coker 1992). 
The important value index (IVI) indicates the relative ecological importance of the woody species in the study area (Kent and Coker 1992). It is determined from the summation of the relative values of density, frequency and dominance of each woody species. Relative density was calculated as the percentage of density of each species divided by the total stem number of all woody species per hectare. Relative frequency of the woody species was computed as the ratio of the frequency of the species to the sum total of the frequency of all woody species. Relative dominance was calculated as the percentage of the total basal area of the woody species out of the total basal areas of all woody species.

The population structure of each woody species in the study area was assessed through histograms constructed by using the density of individuals of each species ( $Y$ axis) categorized into 10-diameter classes ( $X$-axis) (Peter 1996), i.e. $1=<2 \mathrm{~cm} ; 2=2-5 \mathrm{~cm} ; 3=5-10 \mathrm{~cm} ; 4=10-$ $15 \mathrm{~cm} ; 5=15-20 \mathrm{~cm} ; 6=20-25 \mathrm{~cm} ; 7=25-30 \mathrm{~cm} ; 8=$ $30-35 ; 9=35-40$; and $10=>40 \mathrm{~cm}$. Based on the profile depicted in the population structures, the regeneration status of each woody species was determined.

\section{Results}

Species, genera and family richness of woody species

A total of 35 woody species representing 12 families and 20 genera were recorded inside and outside the compound of ORI (Tables 1 and 2). Fabaceae exhibited the highest richness in the woody species followed by Combretaceae, Tiliaceae and Capparaceae. Similarly, the genus Grewia had the highest richness in the woody species followed by Vachellia. The other families and genera were represented by either two or one woody species.

Of the woody species encountered in the study areas, 32 species representing 12 families and 20 genera were recorded inside the ORI compound. Conversely, 24 species representing 10 families and 16 genera were recorded outside the ORI compound (Tables 1 and 2). Inside the ORI compound, Fabaceae exhibited the highest richness of the woody species followed by Tiliaceae, Capparaceae and Combretaceae (Table 1). Outside the ORI compound, still, Fabaceae had the highest richness of the woody species followed by Combretaceae and Tiliaceae (Table 2). The genera represented by the highest richness of the woody species were Grewia and Vachellia inside the ORI compound (Table 1) and Grewia and Combretum and Vachellia outside the ORI compound (Table 2).

Similarities in richness of woody species, families and genera Of the total number of woody species recorded, 21 were encountered both inside and outside the ORI compound, representing a $S_{j}$ of $60 \%$, while 11 of the species were found only inside and three of the species were found only outside the ORI compound (Tables 1 and 2). Similarly, 10 of the 12 families encountered in the study were shared by the areas inside and outside of the ORI compound, representing a $S_{j}$ of about $83 \%$. Also, 16 of the 20 genera $\left(S_{j}=80 \%\right)$ recorded were common to the inside and outside areas of the ORI compound (Tables 1 and 2). Two families, namely, Burseraceae and Rubiaceae, and five genera, namely, Capparis, Commiphora, Gardenia and Maerua, were exclusively recorded inside the ORI compound (Table 1).

\section{Diversity and evenness}

The diversity $\left(\mathrm{H}^{\prime}\right)$ and eveness (E) of woody species were 2.42 and 0.75 inside and 1.63 and 0.52 outside the ORI compound, respectively.

\section{Density, frequency and dominance}

The total mean densities of woody species were 14,215 individuals ha ${ }^{-1}$ inside and 1922 individuals ha ${ }^{-1}$ outside the ORI compound (Tables 1 and 2). The mean densities of woody species ranged between 12,307 and only 0.4 individual ha ${ }^{-1}$ inside the ORI compound (Table 1). Similarly, the mean densities of woody species ranged between 912 and 0.4 individual $\mathrm{ha}^{-1}$ outside the ORI compound (Table 2). The five most densiest woody species were $C$. mopane, $V$. tortilis, Grewia retinervis Burret, C. megalobotrys and Philenoptera violacea (Klotzsch) Schrire inside the ORI compound (Table 1), and $C$. megalobotrys, C. mopane, P. violacea, Philenoptera nelsii (Schinz) Schrire and Combretum hereroense Schinz outside the ORI compound.

The total mean density of woody species was about seven times higher inside (14,215 individuals $\left.\mathrm{ha}^{-1}\right)$, representing an incremental density of 12,293 indidviduals $\mathrm{ha}^{-1}$ (640\%), compared with the outside (1922 individuals $\mathrm{ha}^{-1}$ ) ORI compound. With the exception of six of the species, which showed negative values of increment, the densities of all other woody species commonly shared by the open and exclosed areas exhibited increment in their densities ranging from $51 \%$ ( $V$. nilotica) to $8900 \%$ (G. flava) (Table 3). An exceptionally high regeneration, represented mainly by seedlings, was observed for $C$. mopane in the exclosed area. This clearly provides further empirical evidence for the contribution of area exclosures in enhancing the densities of woody species. Exceptional regeneration (seedlings) was observed inside the ORI compound compared with the open area, where seedlings are almost absent. Those woody species, which exhibited negative increment (e.g. C. megalobotrys) are pioneer species that are favoured by disturbances, which create gaps for their germination, recruitment and growth. Almost all of these species were represented by their juveniles, e.g. P. violacea and Hyphaene petersiana. 
Table 1 List of woody species recorded inside the Okavango Research Institute compound with their family names, mean densities (in descending order), relative densities (RD in \%), frequencies and relative frequencies (RF in \%), dominance, relative dominance (RDO in $\mathrm{m}^{2} \mathrm{ha}^{-1}$ ) and important value index (IVI)

\begin{tabular}{|c|c|c|c|c|c|c|c|c|}
\hline Species & Family & Density & $\mathrm{RD}$ & Frequency & RF & Dominance & $\mathrm{RDO}$ & $\mid \mathrm{VI}$ \\
\hline Colophospermum mopane (Kirk ex Benth.) Kirk ex J. Léonard & Fabaceae & 12,307 & 86.6 & 98.5 & 16.9 & 0.5 & 50.2 & 154 \\
\hline Vachellia tortilis (Forssk.) Galasso \& Banfi & Fabaceae & 444 & 3.1 & 79.4 & 13.6 & 0.3 & 30.9 & 48 \\
\hline Grewia retinervis Burret & Tiliaceae & 285 & 2.0 & 5.9 & 1.0 & $0.0^{*}$ & 0.5 & 4 \\
\hline Croton megalobotrys Müll. Arg. & Euphorbiaceae & 248 & 1.7 & 20.6 & 3.5 & 0.1 & 8.4 & 14 \\
\hline Philenoptera violacea (Klotzsch) Schrire & Fabaceae & 173 & 1.2 & 33.8 & 5.8 & 0.0 & 0.02 & 7 \\
\hline Grewia flavescens Juss. & Tiliaceae & 153 & 1.1 & 25.0 & 4.3 & 0.0 & 0.1 & 6 \\
\hline Vachellia erioloba (E.Mey.) P.J.H.Hurter & Fabaceae & 143 & 1.0 & 66.2 & 11.4 & 0.1 & 8.3 & 21 \\
\hline Grewia bicolor Juss. & Tiliaceae & 112 & 0.8 & 38.2 & 6.6 & 0.0 & 0.2 & 8 \\
\hline Terminalia prunioides Laws. & Combretaceae & 70 & 0.5 & 36.8 & 6.3 & 0.01 & 0.7 & 8 \\
\hline Vachellia nilotica (L.) P.J.H.Hurter \& Mabb. & Fabaceae & 59 & 0.4 & 20.6 & 3.5 & 0.0 & 0.4 & 4 \\
\hline Boscia albitrunca (Burch.) Gilg and Benedict & Capparaceae & 40 & 0.3 & 51.5 & 8.8 & 0.0 & 0.01 & 9 \\
\hline Grewia flava DC. & Tiliaceae & 36 & 0.2 & 7.4 & 1.3 & 0.0 & 0.02 & 2 \\
\hline Dichrostachys cinerea (L.) Wight and Arn. & Fabaceae & 33 & 0.2 & 19.1 & 3.3 & 0.0 & 0.02 & 4 \\
\hline Hyphaene petersiana Klotzsch ex Mart. & Arecaceae & 19 & 0.1 & 5.9 & 1.0 & 0.0 & 0.2 & 1 \\
\hline Combretum albopunctatum Suess. & Combretaceae & 16 & 0.1 & 14.7 & 2.5 & 0.0 & 0.0 & 3 \\
\hline Senegallia mellifera (M. Vahl) Seigler \& Ebinger & Fabaceae & 16 & 0.1 & 7.4 & 1.3 & 0.0 & 0.02 & 1 \\
\hline Searsia tenuinervis (Engl.) Moffett & Anacardiaceae & 15 & 0.1 & 5.9 & 1.0 & 0.0 & 0.0 & 1 \\
\hline Combretum imberbe Wawra & Combretaceae & 7 & 0.1 & 7.4 & 1.3 & 0.0 & 0.0 & 1 \\
\hline Gardenia volkensii K.Schum. & Rubiaceae & 6 & 0.04 & 1.5 & 0.3 & 0.0 & 0.0 & 0.3 \\
\hline Boscia salicifolia Oliv. & Capparaceae & 6 & 0.04 & 1.5 & 0.3 & 0.0 & 0.0 & 0.3 \\
\hline Ximenia americana L. & Olacaceae & 4 & 0.03 & 2.9 & 0.5 & 0.0 & 0.0 & 0.5 \\
\hline Vachellia luederitzii (Engl.) Kyal. \& Boatwr & Fabaceae & 4 & 0.03 & 1.5 & 0.3 & 0.0 & 0.0 & 0.3 \\
\hline Grewia sp. & Tiliaceae & 4 & 0.03 & 4.4 & 0.8 & 0.0 & 0.0 & 0.8 \\
\hline Commiphora africana (A.Rich.) Engl. & Burseraceae & 3 & 0.02 & 2.9 & 0.5 & 0.0 & 0.0 & 0.5 \\
\hline Albizia anthelmintica (A. Rich.) Brongn. & Fabaceae & 3 & 0.02 & 2.9 & 0.5 & 0.0 & 0.0 & 0.5 \\
\hline Maerua angolensis DC. & Capparaceae & 3 & 0.02 & 4.4 & 0.8 & 0.0 & 0.0 & 0.8 \\
\hline Albizia harveyi Fourn. & Fabaceae & 1 & 0.01 & 2.9 & 0.5 & 0.0 & 0.0 & 0.5 \\
\hline Gymnosporia senegalensis (Lam.) Exell & Celastraceae & 1 & 0.01 & 1.5 & 0.3 & 0.0 & 0.0 & 0.3 \\
\hline Senegalia erubescens (Welw. ex Oliv.) Kyal. \& Boatwr. & Fabaceae & 1 & 0.01 & 2.9 & 0.5 & 0.0 & 0.0 & 0.5 \\
\hline Terminalia sericea Burch. ex DC. & Combretaceae & 1 & 0.01 & 2.9 & 0.5 & 0.0 & 0.0 & 0.5 \\
\hline Ziziphus mucronata Willd. & Rhamnaceae & 1 & 0.01 & 4.4 & 0.8 & 0.0 & 0.0 & 0.8 \\
\hline Capparis tomentosa Lam. & Capparaceae & 0.4 & 0.01 & 1.5 & 0.3 & 0.0 & 0.0 & 0.3 \\
\hline Total & & 14,215 & & & & & & \\
\hline
\end{tabular}

*The zero values included in the table are not actually zero, but very small numbers close to zero

The two-sample $t$ test revealed that the exclosed area had significantly $(P=0.0001)$ very high density of all woody species $(14,215 \pm 2036)$ than the open area $(1920 \pm$ 446) (Table 4). Also, 15 (71.4\%) of the 21 woody species that were found in the exclosed and open areas exhibited statistically significant $(P=0.00001-0.04)$ differences in their mean densities (Table 4).

The frequencies of woody species ranged between 98.5 and $1.5 \%$ inside the ORI compound (Table 1) and 85.4 and $0.5 \%$ outside the ORI compound (Table 2).
The five most frequent woody species were $C$. mopane, $V$. tortilis, $V$. erioloba, B. albitrunca and Grewia bicolor Juss. inside the ORI compound (Table 1), and C. mopane, C. megalobotrys, P. violacea, Grewia flavescens Juss. and $V$. tortilis outside the ORI compound (Table 2). A high frequency value indicates a wider distribution of the species in the forest.

Similar to densitiy values, frequencies of more than half of the woody species commonly shared by the open areas and the exclosure showed increment ranging from 
Table 2 List of woody species recorded outside the Okavango Research Institute compound with their family names, mean densities (in descending order), relative densities (RD in \%), frequencies and relative frequencies (RF in \%), dominance, relative dominance (RDO in $\mathrm{m}^{2} \mathrm{ha}^{-1}$ ) and important value index (IVI)

\begin{tabular}{|c|c|c|c|c|c|c|c|c|}
\hline Species & Family & Density & $\mathrm{RD}$ & Frequency & $\mathrm{RF}$ & Dominance & RDO & $\overline{\mathrm{IVI}}$ \\
\hline Croton megalobotrys Müll. Arg. & Euphorbiaceae & 912 & 47.5 & 58.5 & 12.2 & 0.1 & 18.1 & 78 \\
\hline Colophospermum mopane (Kirk ex Benth.) Kirk ex J. Léonard & Fabaceae & 252 & 13 & 85.4 & 17.9 & 0.7 & 73.9 & 105 \\
\hline Philenoptera violacea (Klotzsch) Schrire & Fabaceae & 216 & 11 & 58.5 & 12.2 & $0.0^{*}$ & 1.0 & 24 \\
\hline Philenoptera nelsii (Schinz) Schrire & Fabaceae & 208 & 11 & 7.3 & 1.5 & 0.0 & 0.0 & 13 \\
\hline Vachellia tortilis (Forssk.) Galasso \& Banfi & Fabaceae & 83 & 4.3 & 39.0 & 8.2 & 0.0 & 0.1 & 13 \\
\hline Combretum hereroense Schinz & Combretaceae & 58 & 3.0 & 24.4 & 5.1 & 0.04 & 4.1 & 12 \\
\hline Vachellia nilotica (L.) P.J.H.Hurter \& Mabb. & Fabaceae & 39 & 2.0 & 24.4 & 5.1 & 0.0 & 0.2 & 7 \\
\hline Hyphaene petersiana Klotzsch ex Mart. & Arecaceae & 35 & 1.8 & 26.8 & 5.6 & 0.0 & 0.1 & 8 \\
\hline Grewia flavescens Juss. & Tiliaceae & 29 & 1.5 & 41.5 & 8.7 & 0.0 & 0.0 & 10 \\
\hline Vachellia erioloba (E.Mey.) P.J.H.Hurter & Fabaceae & 29 & 1.5 & 29.3 & 6.1 & 0.01 & 0.7 & 8 \\
\hline Grewia bicolor Juss. & Tiliaceae & 12 & 0.6 & 7.3 & 1.5 & 0.0 & 0.0 & 2 \\
\hline Ximenia americana $\mathrm{L}$. & Olacaceae & 10 & 0.5 & 4.9 & 1.0 & 0.0 & 0.0 & 2 \\
\hline Combretum albopunctatum Suess. & Combretaceae & 8 & 0.4 & 12.2 & 2.6 & 0.0 & 0.02 & 3 \\
\hline Combretum imberbe Wawra & Combretaceae & 8 & 0.4 & 4.9 & 1.0 & 0.02 & 1.9 & 3 \\
\hline Searsia tenuinervis (Engl.) Moffett & Anacardiaceae & 7 & 0.4 & 2.4 & 0.5 & 0.0 & 0.01 & 0.9 \\
\hline Grewia retinervis Burret & Tiliaceae & 5 & 0.3 & 7.3 & 1.5 & 0.0 & 0.0 & 1.8 \\
\hline Dichrostachys cinerea (L.) Wight and Arn. & Fabaceae & 3 & 0.2 & 7.3 & 1.5 & 0.0 & 0.01 & 1.7 \\
\hline Terminalia prunioides Laws. & Combretaceae & 3 & 0.2 & 12.2 & 2.6 & 0.0 & 0.0 & 2.8 \\
\hline Ziziphus mucronata Willd. & Rhamnaceae & 2 & 0.1 & 9.8 & 2.0 & 0.0 & 0.0 & 2.1 \\
\hline Senegalia fleckii (Schinz) Boatwr. & Fabaceae & 0.6 & 0.03 & 2.4 & 0.5 & 0.0 & 0.0 & 0.5 \\
\hline Boscia albitrunca (Burch.) Gilg and Benedict & Capparaceae & 0.6 & 0.03 & 2.4 & 0.5 & 0.0 & 0.01 & 0.5 \\
\hline Albizia anthelmintica (A. Rich.) Brongn. & Fabaceae & 0.5 & 0.03 & 2.4 & 0.5 & 0.0 & 0.0 & 0.5 \\
\hline Gymnosporia senegalensis (Lam.) Exell & Celastraceae & 0.5 & 0.03 & 2.4 & 0.5 & 0.0 & 0.0 & 0.5 \\
\hline Grewia flava DC. & Tiliaceae & 0.4 & 0.02 & 2.4 & 0.5 & 0.0 & 0.0 & 0.5 \\
\hline Total & & 1922 & & & & & & \\
\hline
\end{tabular}

*The zero values included in the table are not actually zero, but very small numbers close to zero

15 to $2046 \%$ inside the ORI compound compared with the corresponding values outside the ORI compound. Nine of the woody species exhibited negative increment values of frequency ranging from -19 to $-354 \%$ (Table 3).

The dominance of woody species ranged between 0.5 and close to $0 \mathrm{~m}^{2} \mathrm{ha}^{-1}$ for 27 of the woody species inside the ORI compound (Table 1), and 0.7 and close to $0 \mathrm{~m}^{2} \mathrm{ha}^{-1}$ outside the ORI compound (Table 2). The three relatively dominant woody species were C. mopane, V. tortilis and C. megalobotrys inside the ORI compound (Table 1), and C. mopane, C. megalobotrys and $C$. hereroense outside of the ORI compound (Table 2).

\section{Important value index}

The IVI of woody species ranged between 154 and $0.3 \%$ inside the ORI compound (Table 1), and 105 and 0.5\% outside the ORI compound (Table 2). The woody species with the highest IVI were $C$. mopane, $V$. tortilis, $V$. erioloba and C. megalobotrys inside the ORI compound (Table 1), and C. mopane, C. megalobotrys, $P$. violacea, $P$. nelsii and $V$. tortilis outside the ORI compound (Table 2).

\section{Population structure and regeneration status}

Assessment of the population structure of woody species inside and outside the ORI compound revealed six general diameter class distribution pattterns (Fig. 2).

1. The first pattern was composed of species that exhibited higher number of individuals at the lowest diameter class and progressively declining numbers with increasing diameter classes (Fig. 2a). This pattern was illustrated by C. mopane, V. erioloba, Dichrostachys cinerea (L.) Wight and Arn., C. imberbe and Senegalia mellifera (M. Vahl) Seigler \& Ebinger inside and only $D$. cinerea outside the ORI compound.

2. The second pattern was formed by species with similar diameter class distribution pattern as the first 
Table 3 Increment (proportion of increment) of mean densities and frequencies of woody species inside the ORI compound in relation to the corresponding values outside the ORI compound

\begin{tabular}{|c|c|c|c|c|}
\hline \multirow[t]{2}{*}{ Species } & \multicolumn{2}{|c|}{ Mean Density } & \multicolumn{2}{|l|}{ Frequency } \\
\hline & Exclosure & Increment (proportion in \%) & Exclosure & Increment (proportion in \%) \\
\hline Colophospermum mopane & 12,307 & $12,055(4784)$ & 98.5 & $13.1(15)$ \\
\hline Vachellia tortilis & 444 & $361(435)$ & 79.4 & $40.4(104)$ \\
\hline Grewia retinervis Burret & 285 & $280(5600)$ & 5.9 & $-1.4(-24)$ \\
\hline Croton megalobotrys & 248 & $-389(-73)$ & 20.6 & $-37.9(-184)$ \\
\hline Philenoptera violacea & 173 & $-43(-20)$ & 33.8 & $-24.7(-73)$ \\
\hline Grewia flavescens & 153 & $124(428)$ & 25.0 & $-16.5(-66)$ \\
\hline Vachellia erioloba & 143 & $114(393)$ & 66.2 & $36.9(126)$ \\
\hline Grewia bicolor & 112 & $100(833)$ & 38.2 & 30.9 (423) \\
\hline Terminalia prunioides & 70 & $67(2233)$ & 36.8 & $24.6(202)$ \\
\hline Vachellia nilotica & 59 & $20(51)$ & 20.6 & $-3.8(-19)$ \\
\hline Boscia albitrunca & 40 & $39(3900)$ & 51.5 & $49.1(2046)$ \\
\hline Grewia flava & 36 & $35.6(8900)$ & 7.4 & $5(208)$ \\
\hline Dichrostachys cinerea & 33 & $30(1000)$ & 19.1 & $11.8(162)$ \\
\hline Combretum albopunctatum & 16 & $8(100)$ & 14.7 & $2.5(21)$ \\
\hline Hyphaene petersiana & 19 & $-16(-46)$ & 5.9 & $-20.9(-354)$ \\
\hline Searsi tenuinervis & 15 & $8(114)$ & 5.9 & $3.5(146)$ \\
\hline Combretum imberbe & 7 & $-1(-12.5)$ & 7.4 & $2.5(51)$ \\
\hline Ximenia americana & 4 & $-6(-60)$ & 2.9 & $-2(-69)$ \\
\hline Albizia anthelmintica & 3 & $2.5(500)$ & 2.9 & $0.5(21)$ \\
\hline Gymnosporia senegalensis & 1 & $0.5(100)$ & 1.5 & $-0.9(-60)$ \\
\hline Ziziphus mucronata & 1 & $-1(-50)$ & 4.4 & $-5.4(-123)$ \\
\hline Total & 14,215 & $12,293(640)$ & & \\
\hline
\end{tabular}

group except that individuals are missing at the higher diameter classes (Fig. 2b). This group consisted of Combretum albopunctatum Suess., G. bicolor, G. flavescens, G. retinervis, S. tenuinervis, G. volkensii, $V$. luederitzii and B. salicifolia inside and $S$. tenuinervis outside the ORI compound.

3. The third pattern was composed of species that showed both hampered seedling/coppice recruitment and missing of individuals at the higher diameter classes (Fig. 2c). This group was exhibited by $T$. prunioides, $V$. tortilis, $P$. violacea, Ximenia americana L., C. megalobotrys, Maerua angolensis DC., Vachellia nilotica (L.) P.J.H.Hurter \& Mabb., G. senegalensis and Commiphora africana (A.Rich.) Engl. inside and C. albopunctatum, C. hereroense and $C$. megalobotrys outside the ORI compound.

4. The fourth pattern consisted of species with individuals represented only in the higher diameter classes (Fig. 2d). This group was represented by Hyphaene petersiana Klotzsch ex Mart. inside and P. violacea, V. erioloba and C. imberbe outside the ORI compound.
5. The fifth pattern was formed by species with missing individuals in one or more of the diameter classes (Fig. 2e). To this group belonged B. albitrunca inside and $H$. petersiana, $V$. nilotica, $V$. tortilis, $D$. cinerea and $S$. tenuinervis outside the ORI compound.

6. The sixth pattern was composed of species with individuals in only one diameter class. This group was exhibited by Albizia harveyi Fourn. and G. flava inside and B. albitrunca, S. fleckii and X. americana outside the ORI compound.

\section{Discussion}

The results revealed that the exclosed area of ORI compound supported more richness in terms of numbers of species, genera and families as well as diversity and evenness of woody species than the open area outside the ORI compound. The inside and outside ORI compound exhibited dissimilarities of 40, 20 and $17 \%$ in their species, genera and family richness of woody species, respectively. This can be attributed to the continuous anthropogenic disturbances, e.g. cutting of trees for fuelwood and construction as well as annual human-induced fires, in 
Table 4 Results from the two-sample $t$ test of mean densities of woody species found in both the inside and outside ORI compound

\begin{tabular}{|c|c|c|c|c|}
\hline \multirow[t]{2}{*}{ Species } & \multicolumn{2}{|c|}{ Mean (individuals ha-1) \pm SEM } & \multirow[t]{2}{*}{$F$ value $^{d f}$} & \multirow[t]{2}{*}{$P$ value } \\
\hline & Inside ORI & Outside ORI & & \\
\hline Colophospermum mopane & $12,307 \pm 2175$ & $252 \pm 64$ & 1041 & $0.00001^{*}$ \\
\hline Vachellia tortilis & $444 \pm 66$ & $83 \pm 34$ & 3.4 & $0.04^{*}$ \\
\hline Grewia retinervis & $285 \pm 189$ & $5 \pm 4$ & 2285 & $0.00001^{*}$ \\
\hline Croton megalobotrys & $248 \pm 102$ & $912 \pm 392$ & 16.3 & $0.0003^{*}$ \\
\hline Grewia flavescens & $153 \pm 83$ & $29 \pm 10$ & 65 & $0.00001^{*}$ \\
\hline Grewia bicolor & $112 \pm 31$ & $12 \pm 11$ & 8.03 & $0.003^{*}$ \\
\hline Terminalia prunioides & $70 \pm 16$ & $3 \pm 2$ & 80.25 & $0.00001^{*}$ \\
\hline Boscia albitrunca & $40 \pm 10$ & $0.6 \pm 0.6$ & 240 & $0.00001^{*}$ \\
\hline Grewia flava & $36 \pm 26$ & $0.4 \pm 0.4$ & 3664 & $0.00001^{*}$ \\
\hline Dichrostachys cinerea & $33 \pm 12$ & $3 \pm 2$ & 30.9 & $0.00001^{*}$ \\
\hline Combretum albopunctatum & $16 \pm 12$ & $8 \pm 4$ & 6.8 & $0.005^{*}$ \\
\hline Ximenia americana & $4 \pm 3$ & $10 \pm 9$ & 12 & $0.001^{*}$ \\
\hline Albizia anthelmintica & $3 \pm 2$ & 0.5 & 14 & $0.0003^{*}$ \\
\hline Ziziphus mucronata & $1 \pm 0.6$ & $2 \pm 2$ & 8.4 & $0.003^{*}$ \\
\hline Gymnosporia senegalensis & $1 \pm 1$ & $0.5 \pm 0.5$ & 3.6 & $0.04^{*}$ \\
\hline Philenoptera violacea & $173 \pm 82$ & $216 \pm 76$ & 1.04 & 0.5 \\
\hline Vachellia erioloba & $143 \pm 26$ & $29 \pm 17$ & 2.02 & 0.16 \\
\hline Vachellia nilotica & $59 \pm 18$ & $39 \pm 14$ & 1.48 & 0.3 \\
\hline Hyphaene petersiana & $19 \pm 13$ & $35 \pm 21$ & 3 & 0.07 \\
\hline Searsia tenuinervis & $15 \pm 12$ & $7 \pm 7$ & 2.5 & 0.09 \\
\hline Combretum imberbe & $7 \pm 3$ & $8 \pm 7$ & 2.6 & 0.1 \\
\hline Total & $14,215 \pm 2036$ & $1920 \pm 446$ & 18.8 & $0.0001^{*}$ \\
\hline
\end{tabular}

$d f$ degrees of freedom $=8,9$

*Statistically significant

addition to heavy browsing and overgrazing, mainly, by domestic animals, but also wild animals in the area outside ORI compound. Conversely, the vegetation and, hence, the woody species inside the ORI compound are protected successfully from these disturbances through the effective and sustained exclosure created by the strong fence.

In an area subjected to disturbance, e.g. deforestation, the establishment of trees depends on a number of factors. When deforested sites are abandoned without being further disturbed, burnt, farmed or weeded, as in the case of the exclosure of the ORI compound, the vegetation would regenerate quickly from plants recruited from the soil seed bank, sprouting shoots from stumps, pre-existing seedlings surviving the disturbance and plants originating from newly dispersed seeds (Garwood, 1989; Teketay, 2005). In time, the process of this continuous regeneration from the dormant soil seed bank and/or arrival of newly dispersed seeds, i.e. seed rain, as well as coppices leads to the increase in the number of individuals of the different woody species and, hence, their richness in species, genera, families, diversity, evenness, densities, frequencies and dominance. This, in turn, contributes to the differences in IVI and population structure of the woody species between exclosed and open areas. However, after the establishment of the exclosure, the rate at which the vegetation and soil seed banks return to predisturbance densities and composition depends on the severity of initial disturbance and frequency of subsequent disturbances, the duration of disturbance activities, the distance from seed sources of tree species and the regeneration strategy of the colonizing species (Garwood, 1989; Teketay, 2005).

The diversity and evenness values recorded for the study area inside the compound of ORI are also higher than those reported from open areas in Shorobe $(H=$ 2.18 and $E=0.6)$ and Xobe ( $H=1.5$ and $E=0.5$ ) (Neelo et al. 2013) and also an exclosed woodland (Island Safari Lodge) $(H=2.16$ and $E=0.6)$ located in close proximity to the present study areas (Neelo et al. 2015) in northern Botswana. The results also concur with those reports from studies on other exclosures (Birhane et al. 2004, 

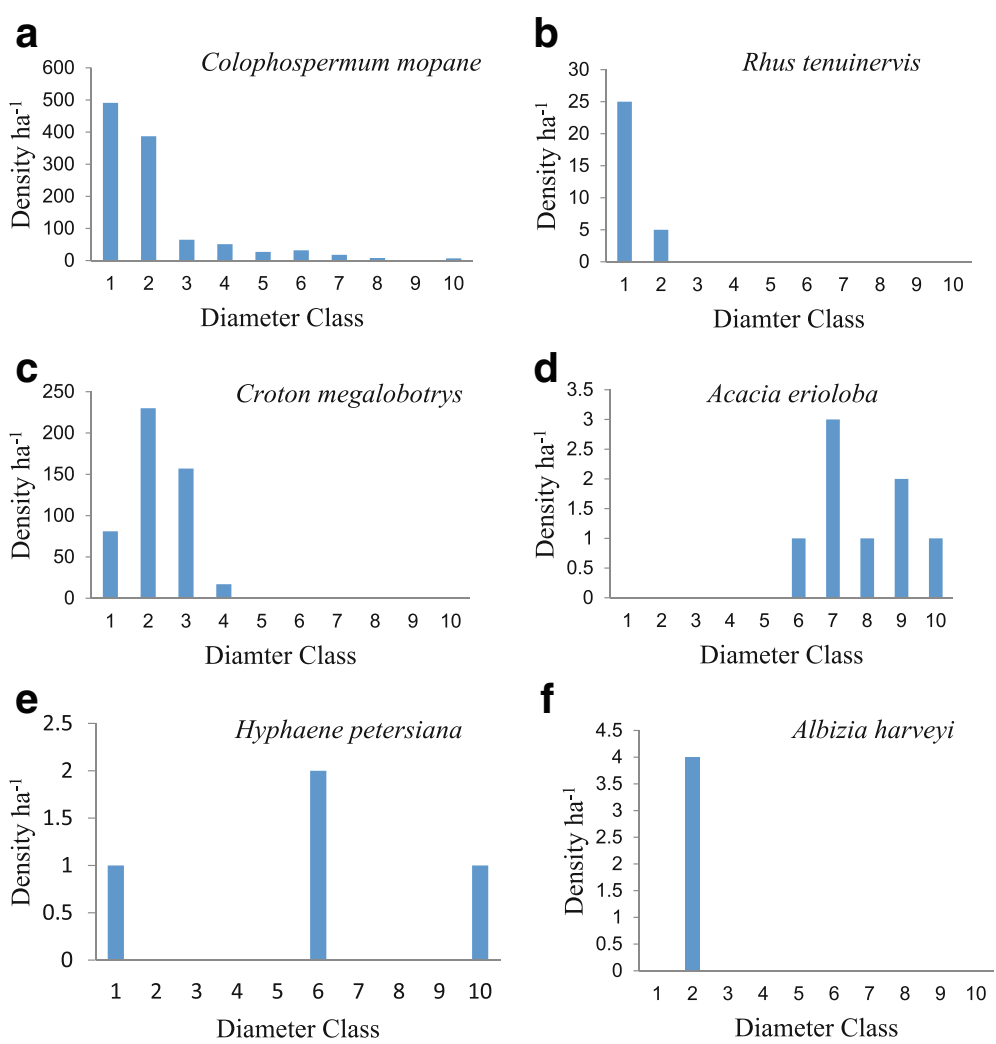

Fig. 2 Population structure of woody species recorded inside $(\mathbf{a}, \mathbf{c}, \mathbf{f})$ and outside $(\mathbf{b}, \mathbf{d}, \mathbf{e})$ ORI compound [diameter class $(\mathrm{DBH}): 1=<2 \mathrm{~cm} ; 2=$ $2-5 \mathrm{~cm} ; 3=5-10 \mathrm{~cm} ; 4=10-15 \mathrm{~cm} ; 5=15-20 \mathrm{~cm} ; 6=20-25 \mathrm{~cm} ; 7=25-30 \mathrm{~cm} ; 8=30-35 \mathrm{~cm} ; 9=35-40 \mathrm{~cm} ;$ and $10=>40 \mathrm{~cm}]$

2006, 2007; Mengistu et al. 2005a, 2005b; Abebe et al. 2006; Yami et al. 2006; Yayneshet et al. 2009; Yayneshet 2011; Mekuria and Veldkamp 2012; Mulugeta 2014; Yirdaw et al. 2014; Kasim et al. 2015). The evenness values ( $E=0.75$ for inside ORI and 0.52 for outside ORI, maximum 1.00) indicate that there is a better equitable distribution of individuals of different woody species in the exclosed than open areas of ORI compound. This could be attributed to the low natural and anthropogenic disturbance in the exclosed area since it is fenced. Fencing excludes the effects of herbivory on species richness and recruitment in plant communties (Jacobs and Naiman 2008; Levick and Rogers 2008). Human-induced disturbances determine the vegetation structure and composition of forests by their influences on the regeneration success of woody species (Cotler and Ortega-Larrocea 2006). The low evenness in areas outside ORI compound can be attributed to excessive disturbance, variable conditions for regeneration and exploitation of some species (Wassie et al. 2005). Similar results were reported by Mapaure and Ndeinoma (2011) who demonstrated that utilization pressure has negatively impacted on the species composition and diversity of woodlands in heavily utilized site in Namibia compared with less utilized and protected Game Park.
In addition, the study areas are located on the fringes and close proximity of the Thamalakane River, which exposes the areas outside of ORI compound to high human and animal disturbances. The daily human and animal traffic to the river for water subjects the areas to these disturbances. As noted by Dutta and Devi (2013), illegal felling, over-exploitation of forest resources, encroachment and domestic grazing are man-induced disturbances that can affect the natural regeneration of woody species and, hence, the forest ecosystem.

Results from the two-sample $t$ test revealed that the exclosed area had much higher density of woody species than the open area. Also, 71.4\% of the woody species recorded from the exclosed area had significantly higher [more than half of them significantly (up to $P=00001$ ) very high] mean densities than the open area. The fact that about 67 and $33 \%$ of the 21 woody species, commonly found in the exclosed and open areas, exhibited increment of mean densities and frequencies, respectively, by more than $100 \%$ (Table 3 ) provides further evidences on the siginificant contribution of exclosures in enhancing densities and frequencies of woody species. In a study that compared three mopane woodland sites in Namibia that have different population densities (densely and sparsely populated as well as a protected Game 
Park) and, hence, experience different utilization levels, significant differences in tree densities were found among the three sites. The sparsely populated site and Game Park had significantly higher tree densities than the densely populated site. There were also significant differences in tree basal areas and biomass among the sites, with significantly lower basal area in the densely populated area than the other two sites (Mapaure and Ndeinoma, 2011). Similarly, other studies (Birhane et al. 2004, 2006, 2007; Mengistu et al. 2005a, 2005b; Abebe et al. 2006; Yami et al. 2006; Yayneshet et al. 2009; Yayneshet 2011; Mekuria and Veldkamp 2012) have shown that area exclosures supported more density of woody plants than open areas.

With regard to the observed population structure of the woody species, only those species (five species from inside and only one species from outside the ORI compound) categorized in the first group exhibited a more or less stable population structure and, hence, healthy regeneration. In particular, C. mopane exhibited an exceptionally high number of seedlings and an overall good stand structure, which was favored by the establishment of the exclosure when compare with the lack of its seedlings outside the ORI compound. The woody species recorded from inside the ORI compound and categorized in the second group are at an initial recovery stages since the vegetation in the ORI compound had been an open grazing area prior to the establishment of the exclosure with the fence. Most of the woody species encountered outside the ORI compound showed hampered recruitment and regeneration, which can be attributed to the different anthropogenic impacts and overgrazing by animals, especially livestock that are allowed to graze freely in the study area. Similar results on better population structure and regeneration status of woody species inside than outside area exclosures, as demonstrated in this study, have been reported by a number of studies (Birhane et al. 2007; Mengistu et al. 2005a, 2005b; Yami et al. 2006; Yayneshet et al. 2009; Yayneshet 2011).

Mapaure and Ndeinoma (2011) have also clearly demonstrated that mopane woodlands in their densely populated site, with high utilization pressure, were structurally different from those of both the protected Game Park and sparsely populated site. They emphasized that the trend is not unexpected in communal areas where population density is high and where resource management regimes are open access in nature. They indicated that the extent to which the woodlands have changed in the densely populated and highly utilized site compared with the neighbouring two sites is a cause for concern. Subsistence harvesting of woody plants by local communities in various sites in southern Africa has also been shown to result in significant changes in the structure of woodlands (Luoga et al. 2004), which, in turn, negatively impacts on local livelihoods (Mapaure and Ndeinoma 2011).

\section{Conclusions}

As their counterparts in other countries of southern Africa, mopane woodlands, which cover the northern-eastern parts of Botswana, provide many goods and ecosystem services that are essential for improving and maintaining human livelihoods in addition to performing many ecological functions. They are also socio-economically important since they provide fuelwood, poles, medicine, mopane worms, thatching, sweeping grass and bee honey to the local communities.

Despite their demonstrated importance to livelihoods and the environment, mopane woodlands in Botswana, and their counterparts in other countries of southern Africa, are declining in size and heavily degraded due to extensive human utilisation, recurrent fire, overgrazing and absence of management practices. This has resulted in change of species composition, decline of diversity, density, frequency and basal area or dominance as well as unstable population structure and hampered regeneration of the woody species.

Area exclosures have been shown to have significant positive effects on the rehabilitation of degraded ecosystems and enhancement of their various services. Results from different studies on area exclosures have demonstrated widely that they contribute towards restoration of vegetation, soil erosion control, improving contents and properties of soil nutrients, soil formation, enhancing soil and plant biomass carbon and generation of animal feed and human food (e.g. edible wild plants and honey) as well as overall improvement of socio-economic conditions of local communities.

The total mean density of woody species was about seven times higher inside, representing an incremental density of 12,293 individuals $\mathrm{ha}^{-1}$ (640\%), compared with the outside ORI compound. The densities of most of the woody species commonly shared by the open and exclosed areas exhibited increment in their densities ranging from 51 to $8900 \%$. It is interesting to note that exceptionally high regeneration was observed for $C$. mopane inside the exclosed area. In general, exceptional regeneration of seedlings was observed inside the ORI compound compared with the open area, where seedlings are almost absent, suggesting the process of recovery of the degraded woodland. Also, frequencies of more than half of the woody species commonly shared by the open areas and the exclosure showed increment ranging from 15 to 2046\% inside the ORI compound compared with the corresponding values outside the ORI compound. Nine of the woody species exhibited negative increment values of frequency ranging from -19 to $-354 \%$. 
The three relatively dominant woody species were $C$. mopane, $V$. tortilis and C. megalobotrys inside the ORI compound and C. mopane, C. megalobotrys and C. hereroense outside of the ORI compound. The woody species with the highest ecological importance (IVI) in the study site were C. mopane, V. tortilis, V. erioloba and C. megalobotrys inside the ORI compound, and C. mopane, $C$. megalobotrys, $P$. violacea, $P$. nelsii and $V$. tortilis outside the ORI compound. The results also revealed that except only five and one woody species from inside and outside the ORI compound, respectively, all other woody species exhibited unstable population structure and, hence, hampered regeneration. This suggests that the exclosed area is still in an initial recovery stage since it had been an open grazing area prior to the establishment of the exclosure with the fence. In the case of the area outside ORI, most of the woody species encountered showed hampered recruitment and regeneration, which can be attributed to the different anthropogenic impacts and overgrazing by animals, especially livestock that are allowed to graze freely in the study area.

Despite the relatively short period of exclosure establishment, results from the present study have further provided empirical evidences on the actual crucial roles played by area exclosures to increase woody species richness, diversity, evenness, density, frequency, dominance and IVI (ecological importance) as well as enhance the population structure and regeneration of the woody species in northern Botswana. Therefore, the results demonstrated that establishment of exclosures can be used as a cheap and convenient management strategy to rehabilitate degraded mopane and other similar woodlands.

Future research is recommended focusing on comparative studies on herbaceous species richness, diversity and density, horizontal and vertical distribution of soil seed banks, species richness in soil microorganisms, plant and soil biomass, plant and carbon pools both above and below ground as well as soil contents and properties inside and outside the ORI compound.

\section{Endnotes}

${ }^{1}$ Source: www.ori.ub.bw (accessed on 30 Dec 2017).

\section{Acknowledgements}

Okavango Research Institute is gratefully acknowledged for supporting the research. The authors are also very grateful for the two anonymous reviewers and Prof. Sandra Luque, the Coordinating Editor, for their constructive comments on an earlier version of this article.

\section{Authors' contributions}

DT designed and conducted the field research, analysed the data and drafted the manuscript. KK, JM, MK, JN, MM and WM participated actively in the data collection and compilation as well as assisted in the write-up of the manuscript. All authors have approved the final manuscript.

\section{Competing interests}

The authors declare that they have no competing interests.

\section{Publisher's Note}

Springer Nature remains neutral with regard to jurisdictional claims in published maps and institutional affiliations.

\section{Author details}

${ }^{1}$ Department of Crop Science and Production, Botswana University of Agriculture and Natural Resources, Private Bag 0027, Gaborone, Botswana.

2University of Botswana, Okavango Research Institute, Private Bag 285, Maun, Botswana.

Received: 29 May 2017 Accepted: 16 January 2018

Published online: 12 February 2018

\section{References}

Abebe MH, Oba G, Angassa A, Weladji R (2006) The role of area enclosures and fallow age in the restoration of plant diversity in northern Ethiopia. Afr J Ecol 44:507-514

Abebe T, Feyssa DH, Kissi E (2014) Area exclosure as a strategy to restore soil fertility status in degraded land in southern Ethiopia. J Biol Chem Res 31:482-494

Abesha GA (2014) Herbaceous vegetation restoration potential and soil physical condition in a mountain grazing land of eastern Tigray, Ethiopia. J Agric Environ Int Dev 108:81-106

Abiyu A, Lemenih M, Gratzer G, Aerts R, Teketay D, Glatzel G (2011) Status of native woody species diversity and soil characteristics in an exclosure and plantations of Eucalyptus globulus and Cupressus lusitanica in northern Ethiopia. Mt Res Dev 31:144-152

Aerts R, Nyssen J, Haile M (2009) On the difference between "exclosures" and "enclosures" in ecology and the environment. J Arid Environ 73:762-763

Angassa A, Oba G (2010) Effects of grazing pressure, age of enclosures and seasonality on bush cover dynamics and vegetation composition in southern Ethiopia. J Arid Environ 74:111-120

Babulo B, Muys B, Mathijs E (2006) Economic valuation methods of forest rehabilitation in exclosures. J Drylands 1:65-170

Babulo B, Muys B, Nega F, Tollens E, Nyssen J, Deckers J, Mathijs E (2009) The economic contribution of forest resource use to rural livelihoods in Tigray, northern Ethiopia. Forest Policy Econ 11:109-117

Bengtsson-Sjörs K (2006) Establishment and survival of woody seedlings in a semi-arid savanna in southern Botswana. Minor field studies 123, Uppsala University, Uppsala, Sweden

Birhane $E$ (2002) The actual and potential contributions of enclosures to enhance biodiversity in drylands of eastern Tigray, with particular emphasis on woody plants. MSc thesis, Swedish University of Agricultural Sciences, Skinnskatteberg

Birhane E, Gebremedihin KM, Tadesse T, Hailemariam M, Solomon N (2017) Exclosures restored the density and root colonization of arbuscular mycorrhizal fungi in Tigray, northern Ethiopia. Ecol Process 6:33

Birhane E, Teketay D, Barklund P (2004) Enclosures as a tool of rehabilitating degraded woodlands in Ethiopia. In: Blay B, Bonkoungou E, Chamshama $\mathrm{SAO}$, Chikamai B (eds) Rehabilitation of degraded lands in sub-Saharan Africa. Forestry Research Network for Sub-Saharan Africa and IUFRO Special Program for Developing Countries, Neulengbach, pp 73-77

Birhane E, Teketay D, Barklund P (2006) Actual and potential contribution of exclosures to enhance biodiversity of woody species in the drylands of eastern Tigray. J Drylands 1:134-147

Birhane E, Teketay D, Barklund P (2007) Enclosures enhance woody species diversity in the dry lands of eastern Tigray, Ethiopia. East Afr J Sci 1:136-147

Cotler H, Ortega-Larrocea MP (2006) Effects of land use on soil erosion in a tropical dry forest ecosystem, Chamela watershed, Mexico. Catena 65:107-117

Descheemaeker K, Muys B, Nyssen J, Poesen J, Raes D, Haile M, Deckers J (2006) Litter production and organic matter accumulation in exclosures of the Tigray highlands, Ethiopia. For Ecol Manag 233:21-35

Descheemaeker K, Nyssen J, Rossi J, Poesen J, Haile M, Raes D, Muys B, Moeyersons J, Deckers S (2006) Sediment deposition and pedogenesis in exclosures in the Tigray highlands, Ethiopia. Geoderma 132:291-314

DeStefano S, Faison E, Compton J, Wattles D (2015) Forest exclosures: an experimental approach to understanding browsing by moose and deer. http:// harvardforest.fas.harvard.edu/sites/harvardforest.fas.harvard.edu/files/publications/ pdfs/DeStefano_MassWildlife_2010.pdf. Accessed on 30 Dec 2017

Dutta G, Devi A (2013) Plant divcersity, population structure and regeneration status in disturbed tropical forests in Assam, northeast India. J For Res 24:715-720 
Ellery K, Ellery W (1997) Plants of the Okavango Delta: a field guide. Tsaro Publisher, Durban

FAO (2002) State of Forest and Tree Genetic Resources in Zimbabwe. FAO, Rome, Italy

Flyman MV (1999) The fate of woody plant seedlings in the presence and absence of large herbivores in a semi-arid savannah. MPhil Thesis, University of Botswana, Gaborone

Garwood NC (1989) Tropical soil seed banks: a review. In: Leck MA, Parker VT, Simpson RL (eds) Ecology of Soil Seed Banks. Academic Press, San Diego and California, pp. 149-209

Getsesellassie H (2012) Effect of exclosure on environment and its socioeconomic contributions to local people in the case study of Halla exclosure, Tigray, Ethiopia. MSc Thesis, Norwegian University of Life Science, Ås

Ghazoul J (ed) (2006) Mopani woodlands and the mopane worm: enhancing rural livelihoods and resource sustainability. Final technical report, DFID, London

Girmay G, Singh BR, Nyssen J, Borrosen T (2009) Runoff and sediment-associated nutrient losses under different land uses in Tigray, northern Ethiopia. J Hydrol 376:70-80

Gratzer G, Abiyu A (2013) The role of exclosures in the diversity and productivity of rural landscapes in North Gondar, Ethiopia. KEF PROJECT (Project 167, 2009-2012), final report. Institute of Forest Ecology, Vienna

Haile G (2012) Effect of exclosure on environment and its socio economic contributions to local people: in the case study of halla exclosure, Tigray, Ethiopia. MSc Thesis, Norwegian University of Life Science, Trondheim

Heath A, Heath R (2009) Field guide to the plants of northern Botswana: including the Okavango Delta. Kew Publishing, Royal Botanic Gardens, Kew

Herrera A (2011) Changes in spatial structure of woody savanna vegetation afte 11 years of exclusion of large herbivores. Minor Field Studies 162, Uppsala University, Uppsala

Hosseinzadeh G, Jalilvand H, Tamartash R (2010) Short time impact of enclosure on vegetation cover, productivity and some physical and chemical soil properties. J Appl Sci 10:2001-2009

Jacobs SM, Naiman R (2008) Large African herbivores decrease herbaceous plant biomass while increasing plant species richness in a semi-arid savanna toposequence. J Arid Environ 72:889-901

Kalaba FK, Quinn CH, Dougill AJ (2013) Contribution of forest provisioning ecosystem services to rural livelihoods in the Miombo woodlands of Zambia. Popul Environ 35:159-182

Käller A (2003) Growth pattern and reproduction of woody vegetation in a semi-arid savanna in southern Botswana. Minor Field Studies 86, Uppsala University, Uppsala

Karekezi S, Ewagata E (1994) Biomass energy use in developing countries: an African perspective. SunWorld 18:3-5

Kasim M, Assfaw Z, Derero A, Melkato M, Mamothe Y (2015) Role of area closure on the recovery of woody species composition on degraded lands and its socio-economic importance in central Rift Valley area, Ethiopia. Int J Dev Res 5:3348-3358

Kent M, Coker P (1992) Vegetation description and analysis: a practical approach. John Wiley and Sons Ltd, England

Krebs CJ (1989) Ecological methodology. Harper Collins Publishers, New York

Kyalangalilwa B, Boatwright JS, Daru BH, Maurin O, van der Bank M (2013) Phylogenetic position and revised classification of Acacia s.l. (Fabaceae: Mimosoideae) in Africa, including new combinations in Vachellia and Senegalia. Botanical Journal of the Linnean Society 172:500-523.

Lawes MJ, Joubert R, Griffiths ME, Boudreau S, Chapman CA (2007) The effect of the spatial scale of recruitment on tree diversity in Afromontane Forest fragments. Biol Conserv 139:447-456

Leife H (2010) Has woody vegetation in a semi-arid savanna changed after 11 years of exclusion of large herbivores. Minor Field Studies 153, Uppsala University, Uppsala

Lemenih M, Kassa H (2014) Re-Greening Ethiopia: History, Challenges and Lessons. Forests 5:1896-1909

Levick S, Rogers K (2008) Patch and species specific responses of savanna woody vegetation to browser exclusion. Biol Conserv 141:489-498

Luoga EJ, Witkowski ETF, Balkwill K (2004) Regeneration by coppicing (resprouting) of miombo (African savanna) trees in relation to land use. Forest Ecol Manag 189:23-35

Magurran AE (2004) Measuring biological diversity. Blackwell Publishing, United Kingdom

Makhado RA, Mapaure I, Potgieter MJ, Luus-Powell WJ, Saidi AT (2014) 'Factors influencing the adaptation and distribution of Colophospermum mopane in southern Africa's mopane savannas-a review'. Bothalia 44(1), Art. \#152, 9 pages. https://doi.org/10.4102/abc.v44i1.152
Makhado RA, Potgieter MJ, Luus-Powell WJ (2016) Nutritional value of Colophospermum mopane as source of browse and its chemical defenses against browsers: a review. J Anim Plant Sci 26:569-576

Makhado RA, Potgieter MJ, Wessels DCJ, Saidi AT, Masehela KK (2012) Use of Mopane woodland resources and associated woodland management challenges in rural areas of South Africa. Ethnobotany Res Appl 10:369-379

Mamo K (2008) Enclosure as a viable option for rehabilitation of degraded lands and biodiversity conservation: the case of Kallu Woreda, southern Wello. MSc Thesis, Addis Ababa University, Addis Ababa

Mapaure I (1994) The distribution of Colophospermum mopane (LeguminosaeCaesalpinioideae) in Africa. Kirkia 15:1-5

Mapaure I, Ndeinoma A (2011) Impacts of local-level utilization pressure on the structure of mopane woodlands in Omusati region, northern Namibia. African J Plant Sci 5:305-313

Mbatha KR, Ward D (2010) Effects of herbivore exclosures on variation in quality and quantity of plants among management and habitat types in a semiarid savanna. Afr J Range Forage Sci 27:1-9

Mekuria W (2013) Conversion of communal grazing lands into exclosures restored soil properties in the semi-arid lowlands of northern Ethiopia. Arid Land Res Manag 27:153-166

Mekuria W, Aynekulu E (2011) Exclosure land management for restoration of the soils in degraded communal grazing lands in northern highlands of Ethiopia. Land Degrad Dev 24:528-538

Mekuria W, Veldkamp E (2012) Restoration of native vegetation following exclosure establishment on communal grazing lands in Tigray, Ethiopia. Appl Veg Sci 15:71-83

Mekuria W, Veldkamp E, Corre MO, Haile H (2011) Restoration of ecosystem carbon stocks following exclosure establishment in communal grazing lands in Tigray, Ethiopia. Soil Sci Soc Am J 75:246-256

Mekuria W, Veldkamp E, Haile H, Gebrehiwot K, Muys B, Nyssen J (2009) Effectiveness of exclosures to control soil erosion and local community perception on soil erosion in Tigray, Ethiopia. Afr J Agric Res 4:365-377

Mekuria W, Veldkamp E, Haile H, Nyssem J, Muys B, Gebirehiwot K (2007) Effectiveness of exclosures to restore degraded soils as a result of overgrazing in Tigray, Ethiopia. J Arid Environ 69:270-284

Mekuria W, Veldkamp E, Tilahun M, Olschewski R (2011) Economic valuation of land restoration: the case of exclosures established on communal grazing lands in Tigray, Ethiopia. Land Degrad Dev 22:334-344

Mengistu T (2001) The role of enclosures in the restoration of woody species in degraded hillsides of Biyo and Tiya, central and northern Ethiopia. MSC thesis, Swedish University of Agricultural Sciences, Skinnskatteberg

Mengistu T, Teketay D, Hulten H, Yemshaw Y (2005a) The role of enclosures in the recovery of woody vegetation in degraded dryland hillsides of central and northern Ethiopia. J Arid Environ 60:259-281

Mengistu T, Teketay D, Hulten H, Yemshaw Y (2005b) The role of communities in closed area management in Ethiopia. Mt Res Dev 25:44-50

Mulugeta G (2014) Vegetation dynamics of area enclosure practices: a case of Gonder Zuria District, Amhara region, Ethiopia. J Nat Sci Res 4:75-82

Mulugeta G, Achenef A (2015) Socio-economic challenges of area exclosure practices: a case of Gonder Zuria Woreda, Amhara region, Ethiopia. J Nat Sci Res 5:123-132

Mureithi SM (2006) The effect of enclosures on rehabilitation of degraded semiarid land in Lake Baringo Basin, Kenya. MSc. Thesis, Ghent University, Ghent

Mureithi SM, Verdoodt A, Gachene CKK, Njoka JT, Wasonga VO, De Neve S, Meyerhoof E, Van Ranst E (2014) Impact of enclosure management on soil properties and microbial biomass in a restored semi-arid rangeland, Kenya. J Arid Land 6:561-570

Musvoto C, Mapaure I, Gondo T, Ndeinoma A, Mujawo T (2007) Reality and preferences in community Mopane (Colophospermum mopane) woodland management in Zimbabwe and Namibia. Int J Environ Ecol Eng 1:59-63

Naudts J, De Geyndt K, Nyssen J, Deckers J, Haile M, Moeyersons J, Poesen, J (2015) The trap efficiency for sediment and carbon in exclosures on steep slopes. A Case Study from the Tembien highlands, Tigray. http:// www.beep.ird.fr/collect/bre/index/assoc/HASH40df.dir/23-615-624.pdf. Accessed on 30 Dec 2017

Nedessa B, Ali J, Nyborg I (2005) Exploring ecological and socio-economic issues for the improvement of area enclosure management: a case study from Ethiopia. DCG (Drylands Coordination Group), Oslo

Neelo J, Kashe K, Teketay D, Masamba W (2015) Ethnobotanical survey of woody plants in Shorobe and Xobe villages, northwest region of Botswana. Ethnobot Res Appl 14:367-379 
Neelo J, Teketay D, Kashe K, Masamba W (2015) Stand structure, diversity and regeneration status of woody species in open and exclosed dry woodland sites around molapo farming areas in the Okavango Delta, northeastern Botswana. Open J Forestry 5:313-328

Neelo J, Teketay D, Masamba W, Kashe K (2013) Diversity, population structure and regeneration status of woody species in dry woodlands adjacent to Molapo farms in northern Botswana. Open J Forestry 4:138-151

Peters CM (1996) The ecology and management of non-timber forest resources. World Bank Technical Paper 322, Washington

Roodt V (1993) The shell field guide to the common trees of the Okavango Delta and Moremi Game Reserve. Shell Oil (Pty) Ltd, Gaborone

Roodt V (1998) Trees and shrubs of the Okavango Delta. Shell Oil (Pty) Ltd, Gaborone

Sapkota IP, Tigabu M, Oden PC (2009) Spatial distribution, advanced regeneration and stand structure of Nepalese Sal (Shorea robusta) Forest subject to disturbances of different intensities. For Ecol Manag 257:1966-1975

Setshogo MP (2002) Common names of some flowering plants of Botswana. $\mathrm{FAO}$, Rome

Setshogo MP (2005) Preliminary checklist of the plants of Botswana. Southern African Botanical Diversity Network, Pretoria

Setshogo MP, Venter F (2003) Trees of Botswana: names and distribution. Southern African Botanical Diversity Network, Pretoria

Shackleton CM, Shackleton SE, Buiten E, Bird N (2007) The importance of dry woodlands and forests in rural livelihoods and poverty alleviation in South Africa. Forest Policy Econ 9:558-577

Sheil D (1999) Tropical forest diversity, environmental change and species augmentation: after the intermediate disturbance hypothesis. J Veg Sci 10:851-860

Siebert F, Eckhardt H C, Siebert, S J (2010) The vegetation and floristics of the Letaba exclosures, Kruger National Park, South Africa. Koedoe 52(1), Art. \#777, 12 pages. DOl: https://doi.org/10.4102/koedoe.v52i1.777

Tekalign M (2010) The role of area exclosures for biodiversity conservation and its contribution to local livelihoods the case of Biyo-Kelala area exclosures in Ada'a wereda. MSc Thesis, Addis Ababa University, Addis Ababa

Teketay D (2005) Seed and regeneration ecology in dry Afromontane forests of Ethiopia: I. Seed production - population structures. Tropical Ecology 46:2944

Teketay D, Lemenih M, Bekele T, Yemshaw Y, Feleke S, Tadesse W, Moges Y, Hunde T, Nigussie D (2010) Forest resources and challenges of sustainable forest management and conservation in Ethiopia. In: Bongers F, Tennigkeit T (eds) Degraded forests in eastern Africa: management and restoration, Earthscan, London, United Kingdom, pp 19-63

Teketay D, Sethebe B, Madome J, Murray-Hudson F (2009) Woody species in ORI campus. Okavango Research Institute. University of Botswana, Maun

Tietema T, Ditlhogo M, Tibone C, Mathalaza N (1991) Characteristics of eight firewood species of Botswana. Biomass Bionergy 1:41

Tilahun M, Olschewski R, Kleinn C, Gebrehiwot K (2007) Economic analysis of closing degraded Boswellia papyrifera dry forest from human interventions-a study from Tigray, northern Ethiopia. Forest Policy Econ 9:996-1005

Timberlake J (1980) Handbook of Botswana acacias. Ministry of Agriculture, Gaborone

Tsetargachew A (2008) Area closure as a strategy for land management: a case study at Kelala Dalacha enclosure in the central rift valley of Ethiopia. MSC Thesis, Addis Ababa University, Addis Ababa

UNESCO (United Nations Educational, Scientific and Cultural Organization) (2015) Okavango Delta. http://whc.unesco.org/en/list/1432. Accessed 30 Dec 2017

van Wyk B, van Wyk P (1997) Field guide to trees of southern Africa. Struik Nature, Cape Town

van Wyk B, van Wyk P (2007) How to identify trees in southern Africa. Struik Nature, Cape Town

Venkateswaran R, Parthasarathy N (2003) Tropical dry evergreen forests on the Coromandel coast of India: structure, composition and human disturbance. Ecotropica 9:45-58

Verdoodt A, Mureithi SM, van Ranst E (2010) Impacts of management and enclosure age on recovery of the herbaceous rangeland vegetation in semi-arid Kenya. J Arid Environ 74:1066-1073

Verdoodt A, Mureithi SM, Ye L, van Ranst E (2009) Chronosequence analysis of two enclosure management strategies in degraded rangeland of semi-arid Kenya. Agric Ecosyst Environ 129:332-339

Vetaas OR (1997) Spatial and temporal vegetation changes along a moisture gradient in northeastern Sudan. Biotropica 25:164-175
Wassie A, Teketay D, Powell N (2005) Church forests in North Gonder Administrative Zone, northern Ethiopia. Forests, Trees Livelihoods 15:349-373

Woollen E, Ryan CM, Baumert S, Vollmer F, Grundy I, Fisher J, Fernando J, Luz A, Ribeiro N, Lisboa SN (2016) Charcoal production in the Mopane woodlands of Mozambique: what are the trade-offs with other ecosystem services? Phil Trans R Soc B 371:20150315 https://doi.org/10.1098/rstb.2015.0315

Yami M, Gebrehiwot K, Stein M, Mekuria W (2006) Impact of area enclosures on density, diversity, and population structure of woody species: the case of May Ba'ati-Douga Tembien, Tigray, Ethiopia. Ethiopian J Nat Resour 8:99-121

Yami M, Gebrehiwot K, Stein M, Mekuria W (2007) Impact of area enclosures on density and diversity of large wild mammals: the case of may Ba'ati, Douga Tembien District, Central Tigray, Ethiopia. East Afr J Sci 1:55-68

Yami M, Mekuria W, Hauser M (2013) The effectiveness of village bylaws in sustainable management of communitymanaged exclosures in northern Ethiopia. Sustain Sci 8:73-86

Yayneshet T (2011) Restoration of degraded semi-arid communal grazing land vegetation using the exclosure model. Int I Water Resour Arid Environ 1:382-386

Yayneshet T, Eik LO, Moe SR (2009) The effects of exclosures in restoring degraded semi-arid vegetation in communal grazing lands in northern Ethiopia. J Arid Environ 73:542-549

Yimer F, Alemu G, Abdelkadir A (2015) Soil property variations in relation to exclosure and open grazing land use types in the Central Rift Valley area of Ethiopia. Environ Syst Res 4:17

Yirdaw E, Tigabu M, Lemenih M, Negash M, Teketay D (2014) Rehabilitation of degraded forest and woodland ecosystems in Ethiopia for sustenance of livelihoods and ecosystem services. In: Katila P, Galloway G, de Jong W, Pacheco P, Mery G (eds) Forest under pressure-local responses to global issues. IUFRO world series volume 32. International Union of Forest Research Organizations (IUFRO), Vienna, pp 299-313

Young S (2015a) Exclosures in big game management in Utah. http://journals. uair.arizona.edu/index.php/jrm/article/download/4864/4475. Accessed 30 Dec 2017

Young TP (2015b) Kenya Long-term Exclosure Experiment (KLEE). http://tpyoung. ucdavis.edu/KLEE/. Accessed 30 Dec 2017

Zar J (1996) Biostatistical analysis. Prentice-Hall Inc., New Jersey

\section{Submit your manuscript to a SpringerOpen ${ }^{\circ}$ journal and benefit from:}

- Convenient online submission

- Rigorous peer review

- Open access: articles freely available online

- High visibility within the field

- Retaining the copyright to your article

Submit your next manuscript at springeropen.com 